熱分解生成物に関する研究

第 1 報 ポリエチレン

(1963 年 5 月 16 日受理)

神戸博太郎* . 柴 崎 芳夫*

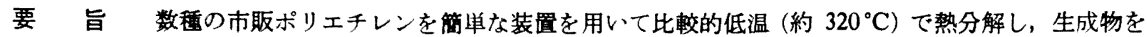
ガスクロマトグラフにより分析し，得られたピークを系統的に同定した。分解生成物中には主として室温で液 体の炭化水素が生し，炭素数 7 9の n-パラフィンおよび $n$-オレフィンと思われる物質が比較的多いが特に きわ代って多く生成する炭化水素はない。またエチレンモノマーの生成量はきわめて少ないから，ポリエチレ ン主鎖の切断が完全にランダムに起こるものと考えられる。同し炭秦数で比較すると， $n$-パラフィンと $n$-オ レフィンの生成量はほぼ等しい。
\end{abstract}

\section{1. 緒言}

高分子物質の熱分解生成物をガスクロマトグラフ（以 下ガスクロ上略記する)を用いて分析しその成分を定量 した例は数多くあるが，ポリエチレンの熱分解生成物に ついてこの方法で采茫的に分析した例はまだないようで ある。ガスフロを用いる上物質の分離は非常に容易であ るが，末知物質の推定およびその同定のためには，予想 されるすべての物卧齐ガスクロに導入して保持時間の一 致する物質を探し出さなければならない。近年末知物質 の推定および同定采統的に行なう方法が種々考案され ているのテ，これらの方法によりポリェチレンの熱分解 生成物を采統的に分析し，成分の同定を試みた。なお以 下に述べるような保持容量ならびに臭素付加法を併用す るガスクロマトクララフ法によりピークの内容を推定する ことはややもする之誤るおそれもあるが，試料の内容お よび熱分解による鎖の切れ方を考慮に入れると今回はそ のような方法でも誤ることがないるのと考えられる。こ の研究では特に熱分解生成物中に主として含まれる成分 の炭素数を決定し，同し炭素数の物質についてはパラ フィン系の成分とオレフィン采の成分の量の割合を調 ベた。

\section{2. 実験方法}

ポリエチレンの熱分解は Fig. 1 に示すような届曲し たガラス管の一端に試料を封入し, 電熱器で一定温度 (約 $320^{\circ} \mathrm{C}$ ) に加熱して行なった。生成した熱分解生成物 の一部を室温の水で汾却してガラス管の他端に凝縮さ せ, 室温で液体の成分と気体の成分とをそれぞれ注射器 で採取し，ガスクロで分析した。常圧で沸点 $320^{\circ} \mathrm{C}$ 以 下の分解生成物は加熱部 a から点発してくるが，そのう ち高沸点成分はガラス管の折れ曲った部分に到達するま でに空気によって冷却されて液化し，再び加熱部に還流

\footnotetext{
* 東京大学航空研究所 (東京都目黒区駒場町 856)
}

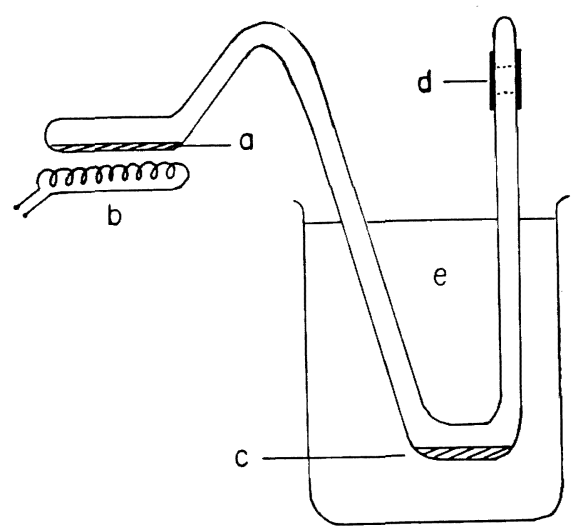

a : Sample, b: Electric heater, c: Degradation products, d: Rubber tube, e: Cold water

Fig. 1. Glass tube assembly as apparatus.

されてそのうちの一部分は再分解される。ガラス管の折 れ曲った部分で一種の分留が行なわれ, 本研究で使用し た分解管では $n$-デカン (沸点 $174^{\circ} \mathrm{C}$ ) より沸点の低いも のだけがガラス管の折曲りの部分を越えて, 水で泠却さ

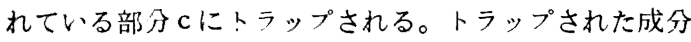
を中沸点成分とし, 冷却部分にトラップされない気体成 分を低沸点成分とする。

広範囲に沸点の異なる物質を一段カラムで一度に分析 することは困難であるが，Fig. 1 に示す熱分解管を使用 すると熱分解と同時にその生成物を高沸点成分 (室温で グリース状) と中沸点成分 (室温で油状) 上低沸点成分 (室 温でガス状)とに分離できろので，ガスクロで分析するの に好都合である。約 $2 \mathrm{~g}$ の試料を $320^{\circ} \mathrm{C}$ で 10 時間く らい加熱する上 60 70\% は室温で液体つ炭化水素(中 沸点成分)による。

ガスクロは島津製作所製の GC-2 A 型(熱伝導型)を 使用した。カラムは銅製コイル状で，充てん剂は市販の 
Dioctyl phthalate(DOP)を Celite に $25 \%$ 含ませたも の, High vacuum oil(HVO)を Celite に $25 \%$ 含ませ たもの, Diethyl formamid(DEF)を Celite に 20\% 含 ませたものを使用した。

用いた試料は市販の高密度, 中密度, 低密度のポリエ チレンである。高密度ポリエチレンは三井化学のハイゼ ックス 5000, ハイゼックス 7000 の 2 種, 中密菨ポリエ チレンは住友化学のスミカセン MF-40, 低密度ポリエ チレンは住友化学のスミカセン F-70 を用いた。

\section{3. 結果と考察}

\section{1 液体成分について}

熱分解生成物の主要部分である室温で液体の成分 (中 沸点成分) は, ポリエチレンの化学構造から考えて主と してパラフィン系およびオレフィン系の炭化水素の混合 物であろうと予想される。DOP カラム (内径 $4 \mathrm{~mm}$ ) を 用いたガスクロマトグラムの典型的な一例を Fig. 2 に 示す。

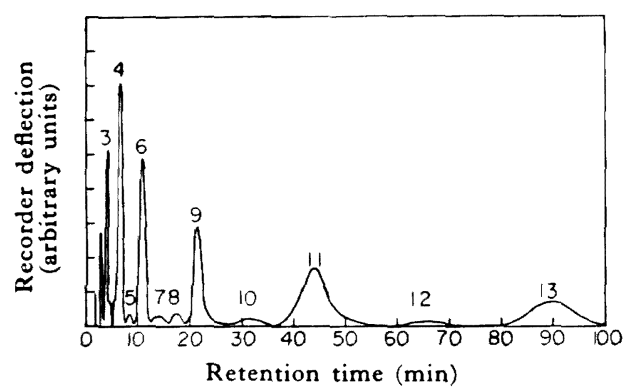

Column: Dioctyl phthalate on celite $3 \mathrm{~m}, 100^{\circ} \mathrm{C}$, Carrier gas: $\mathrm{N}_{2} 30 \mathrm{ml} / \mathrm{min}$

Fig. 2. A typical gas chromatogram of the liquid fraction of the thermal degradation product of polyethylene.

前記 4 種のポリェチレンについて同じ条作で熱分解 し, その生成物の室温で液体の成分をガスクロで分析し たが, 得られたガスクロマトグラムに試料による差異は 認められなかった。また真空 $\left(10^{-8} \mathrm{mmHg}\right)$ 中に封じて 熱分解した場合の熱分解生成物についての分析結果も, 空気の存在する状態で封して熱分解した場合と変わりな くふんい気の相違による有意の差は認められなかった。

Tenney ${ }^{1)}$ は各種同族列の化合物について相対保持容 量の対数を沸点に対してプロットするとほぼ直線が得ら れることを見出し，この関保を用いて相対保持容量の值 から株知物質の沸点索決定する方法を示した。DOP 力 ラムを用いた場合には $n$-パラフィンと $n$-オレフィンと が分離されず，同一炭素数のものは同一のピークに重な っている。純試薬索用いて Fig. 2 の第 4 のピークは $n$ ペンタンおよび $n$-ペンテンであり, 第 5 のピークは $n$ -

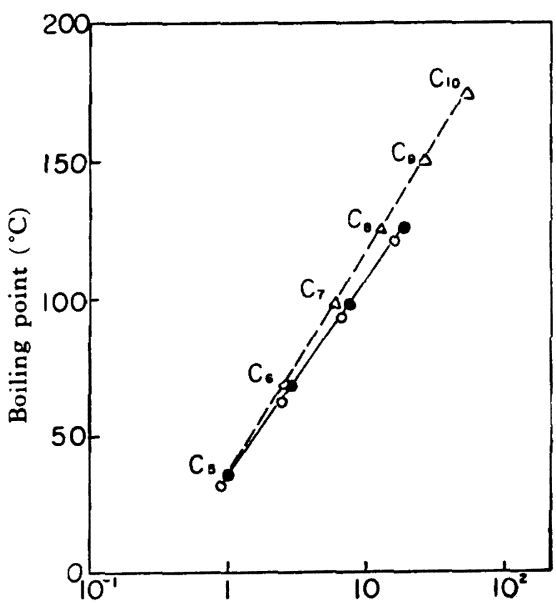

Relative retention volume (n-pentane $=1$ ) DOP $3 \mathrm{~m}, 100^{\circ} \mathrm{C}, \mathrm{N}_{2} 30 \mathrm{ml} / \mathrm{min}$, HVO $3 \mathrm{~m}, 70^{\circ} \mathrm{C}, \mathrm{N}_{2} 20 \mathrm{ml} / \mathrm{min}$

$\triangle:$ Normal hydrocarbons (DOP)

: $n$-Paraffinic hydrocarbons (HVO)

: $n$-Olefinic hydrocarbons (HVO)

Fig. 3. Identification of normal and olefinic hydrocarbons by Tenney's plots.

ヘキサンおよび $n$ 一へキセンに相当するここを確かめた ので, Tenney の方法を Fig. 2 の結果に適用し, Fig. 3 に示すように $n$-ペンタンを基隻にとり，n-ペンタン に対する $n$-ヘキサンの相対保持容量を求め, これらの 対数をそれぞれの沸点に対してプロットし，この 2 点在 結ふ值線を延脣した直線をつくり，n-パラフィンの沸点 の表と, Fig. 2 の各ピークの相対保持容量の值とから Fig. 2 のピークの中で第 6 , 第 9 , 第 11 , 第 13 のピーク がこの直線に乗ることを見出した。そこで第 4 は $n$-ペ ンタンと $n$-ペンテン, 第 5 は $n$-ヘキサンと $n$-へキセ ン, 第 6 は $n$-ヘプタンと $n$-ヘプテン, 第 9 は $n$-オク タンレ $n$-オクテン, 第 11 は $n$-ノナンレ $n$-ノネン, 第 13 は $n$-デカンと $n$-デセンであると推定し, 各 $n$-パラ フィンについては純試萫卒用いて確認した。残りの小さ なピークは枝分かれしたパラフィンまたはオレフィン類 と考えられる。

DOP カラムを用いた場合には $n$-パラフィンと $n$-オ レフィンとが分離されないので，分解生成物中の炭素数 による成分の分布を調べるには好都合である。n-パラ フィンとnーオレフィンの相対感度が等しいと仮定して, $\mathrm{James}^{2)}$ が求めた炭素数の異なる $n$-パラフィンの 1 モル あたりの相対感度の值を用いて，Fig. 2 のピーク面稹か ら算出した各炭素数の炭化水素の相対的生成量を Fig. 4 に示す。これより特定の炭素数のものが特伅多量任生成 することはなく,炭素数 7 9の $n$-パラフィンおよび $n$ オレフィンと思われる物質が比較的多い。Madorsky ${ }^{8),()}$ 


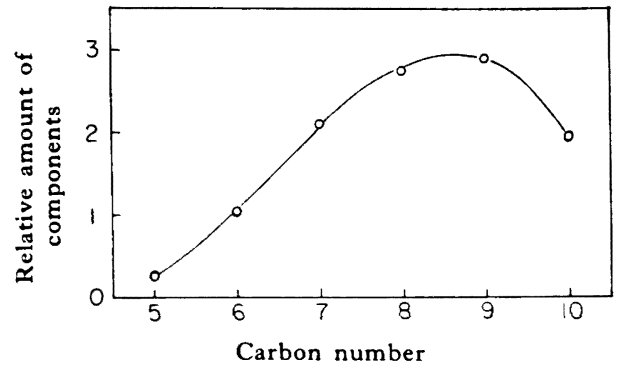

Fig. 4. Relative amounts of components of the thermal degradation product of polyethylene, estimated from peak areas of Fig. 2 with relative sensitivity values by James' ${ }^{2}$.

は質量分析計による分析結果より炭素数 4 のものがもっ とも多く生成するという結論を出し，それに基いた熱分 解機構の考察5) もあるが，これは熱分解装置，熱分解温 度および熱分解生成物の採取の仕方が相違するためであ ろう。比較的低温でゆっくり熱分解すると主鎖がランダ 厶に切断し，デカン程度以下の分子量に切断されたもの がトラップされ，より大きな分子は還流されて再分解さ れるので室温で液体の部分では炭素数 7 9 9 n-パラ フィンおよび $n$-ナレフィンが主成分となるためであろ う。

井上ららはポりエチレン分子は屈曲しやすいために, short range の連鎖移動が起こり, 結局ポリマーラジカ ルの末端より炭素数 3 ないし 4 のものが巻き取られてい くものと思われると述へているが， $320^{\circ} \mathrm{C}$ 付近の比較的 低温で熱分解した場合の 分解生成物の 分析的研究から は, 特に short range の巻き取り機構を考慮する必要 はないと思われる。

液体としてトラップされる熱分解生成物の成分の相対 的割合は分解時間によってあまり変化しないように思わ れる。

Fig. 5 に示すように HVO カラム (内径 $4 \mathrm{~mm}$ ) を用 いて分析すると，DOP を用いた場合にそれぞれの炭素 数の炭化水素に相当したピークが，いずれも二つに分離 した。いずれのピークがパラフィンでいずれがオレフィ ンに属するかを決定するため，採取した液体成分を臭素 水と反応させ，オレフィン系列に属する炭化水素に臭素 を付加させた。臭素を付加すると分子量の小さなものは 水に溶解して除かれ，分子量の大きなものは保持時間が きわめて增大するので, ガスクロのピークの中のオレ フィンに相当するピークを完全に除くことができる。 Fig. 5 で斜線を施こしたピークはオレフィン采炭化水 素に相当するものである。まずペンテン-1 を用いてそ のピークを同定してから Fig. 3 に示すように Tenney のプロットを用いて, $n$-パラフィン系列に平行に引いた

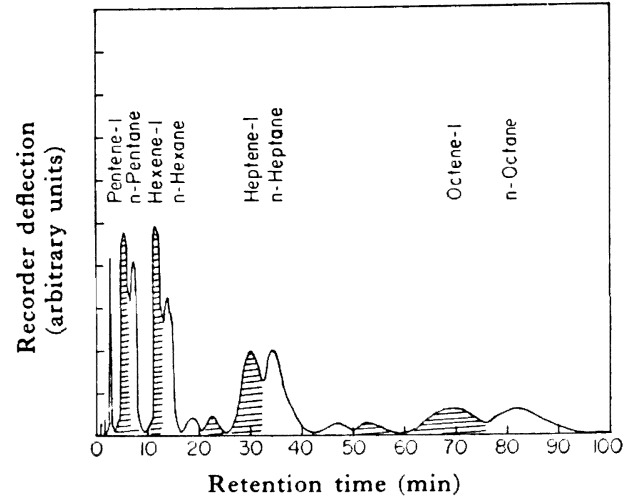

Column: High vacuum oil on celite $3 \mathrm{~m}, 70^{\circ} \mathrm{C}$, Carrier gas : $\mathrm{N}_{2} 20 \mathrm{ml} / \mathrm{min}$

Fig. 5. Gas chromatogram of the liquid fraction of the thermal degradation product of polyethylene.

直線上に乗るピークをそれぞれへキセン-1, ヘプテン-1， オクテンー1 と決定した。

$n$-パラフィン采列と $n$-オレフィン系列の炭化水素の 相対感度が 同じ炭素数のものでは等しいと仮定すると， ピーク面積の比から前記の熱分解条件では $n$-パラフィ ン系列と $n$-オレフィン系列とがほぼ等量ずつ生成する ことがわかった。

これらのピークの間に点在する小さなピークはイソパ ラフィン, イソオレフィンおよびジェン類であろうと思 われる。

\section{2 気体成分について}

生成量は液体成分に比べてきわめて少量であるが，同 様にして室温で気体の成分の分析を行なった。Fig. 6 に $22^{\circ} \mathrm{C}$ にて HVO カラムで分析した結果, Fig. 7 に $19^{\circ} \mathrm{C}$ にてDEF カラムで分析したガスクロマトグラムを示 す。斜線を施こしたピークは臬素水と反応させると消え ることから，分子中に二重結合を持つ化合物である。 Fig. 6 および Fig. 7 を比較すると, 斜線を施こしたピ ークとそうでないピークの位羁が入れかわっていること がわかる。すなわち極性の弱いHVO では沸点順にピー クが現われ，極性の強い DEF では沸点は低くとも二重 結合を持つ炭化水素の方が後から現われる。この関係を Fig. 8 に示す。

Fig. 7 のブテン-1 と $n$-ペンタンの間に現われる二 つのピークは具素水で処理すると消えること, DEF の カラムでピークの発現が遅れること, $n$-ブタノールから 硫酸で脱水して得られた試料について得られたピークと の比較から，それぞれ trans-プテン-2 执よび cis-ブテ ン-2 であることを確認した。ポリェチレンの種類によ らず, $n$-プタン, ブテン-1, trans-ブテン-2, cis-ブテ 
Table 1. Peak areas of $C_{4}$ hydrocarbons.

\begin{tabular}{|c|c|c|c|c|c|c|c|c|}
\hline \multirow[t]{3}{*}{ Experment No. } & \multicolumn{2}{|c|}{1} & \multicolumn{2}{|c|}{2} & \multicolumn{2}{|c|}{3} & \multicolumn{2}{|c|}{4} \\
\hline & \multicolumn{2}{|c|}{$\mathrm{F}-70$} & \multicolumn{2}{|c|}{ F-70 } & \multicolumn{2}{|c|}{$\$ 7000$} & \multicolumn{2}{|c|}{$\# 7000$} \\
\hline & $\mathrm{cm}^{2}$ & $\%$ & $\mathrm{~cm}^{2}$ & $\%$ & $\mathrm{~cm}^{2}$ & $\%$ & $\mathrm{~cm}^{2}$ & $\%$ \\
\hline$n$-Butane & 10.4 & 39.5 & 7.35 & 39.3 & 12.5 & 41.5 & 6.0 & 42.4 \\
\hline Butene-1 & 12.7 & 48.5 & 8.84 & 47.3 & 13.7 & 44.0 & 6.5 & 45.7 \\
\hline trans-Butene-2 & 1.66 & 6.3 & 1.35 & 7.2 & 2.4 & 7.8 & 1.0 & 7.0 \\
\hline cis-Butene-2 & 1.47 & 5.6 & 1.20 & 6.4 & 2.5 & 8.1 & 0.8 & 5.6 \\
\hline
\end{tabular}

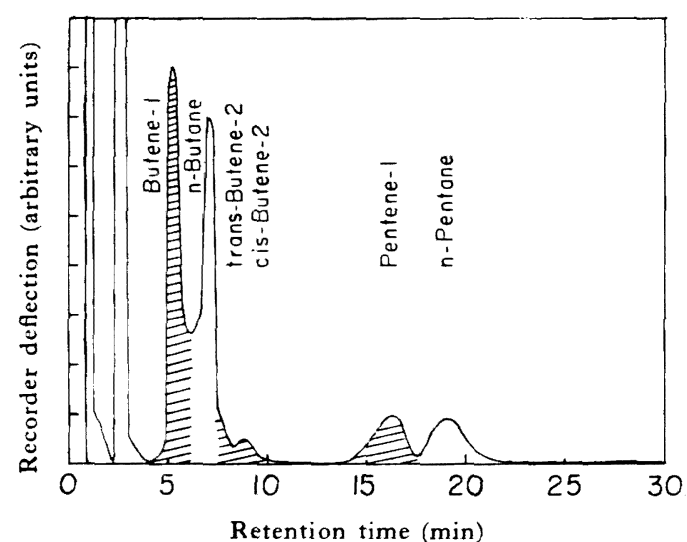

Column: High vacuum oil on celite $3 \mathrm{~m}, 22^{\circ} \mathrm{C}$, Carrier gas: $\mathrm{N}_{2} 26 \mathrm{ml} / \mathrm{min}$

Fig. 6. Gas chromatogram of the gas fraction of the thermal degradation product of polyethylene.

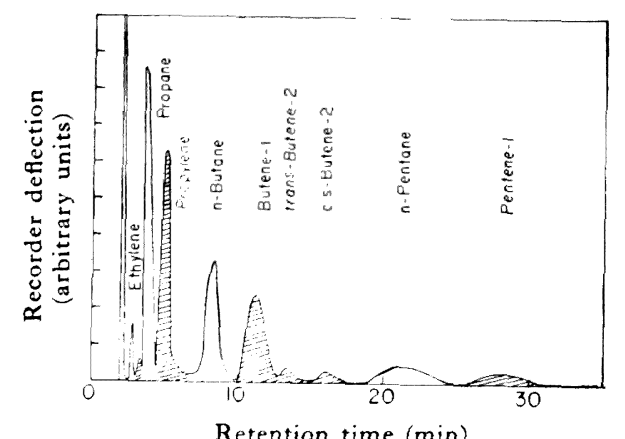

Column: Diethyl formamid on celite $3 \mathrm{~m}, 19^{\circ} \mathrm{C}$,

Carrier gas: $\mathrm{N}_{2} 30 \mathrm{ml} / \mathrm{min}$

Fig. 7. Gas chromatogram of the gas fraction of the thermal degradation product of polyethylene.

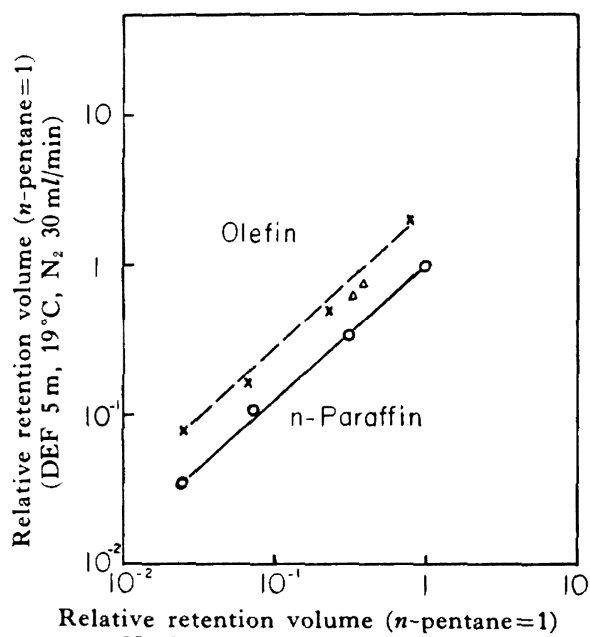

(HVO $3 \mathrm{~m}, 22^{\circ} \mathrm{C}, \mathrm{N}_{2} 26 \mathrm{ml} / \mathrm{min}$ )

Fig. 8. Identification of normal and olefinic hydrocarbons.

ン-2 の生成する割合は同じであった。また分解時間の 影響もほとんどない。この結果を Table 1 に示す。

熱分解管の加熱部分に残存する黑かっ色のグリース状 成分 (高沸点成分上末分解ボリエチレンとの混合物) はガ スクロによる分析が困難なので分析しなかった。

\section{4. 結言}

以上述べたような簡単な熱分解方法およびガスクロに よる分析方法では, 用いた市販のポリエチレンの重合法 または枝分れの程度の相違の熱分解生成物に及ぼす影響 は, 室温で液体の成分および気体の成分のいずれにも認 められなかった。

真赀中および空気の存在する状態での熱分解生成物の 分析の結果, ふんい気の影響は認められなかった。

熱分解生成物は主として $n$-パラフィン系列, $n$-オレ フィン系列で, 枝分かれした炭化水素はきわめて少ない。 比較的低温で長時間熱分解すると主鎖がランダムに切 断し, 炭菜数 7 9 の炭化水素が比較的多く生成するが， 
特定の炭素数のものが特に多量に生成するということは 認められなかった。

同じ炭素数の $n$-パラフィンと $n$-オレフィンの生成量 はほとんど等しい。

付 毁：本研究は昭和 35 年 5 月 27 日の第 9 回高分子学 会年次大会において発表した。本研究に対し種々有益な示唆を与 えられた三田達, 五十嵐正一両氏に感謝する。
文献

1) H. M. Tenney: Anal. Chem., 30, 2(1958)

2) A. T. James: Mfg Chemist., 26, 5(1955)

3) S. L. Madorsky, S. Straus, D. Thompson, L. Williamson: J. Polymer Sci., 4, 639 (1949)

4) S. L. Madorsky, S. Straus: J. Res. Natl. Bur. Std., 53, 2553(1954)

5）井上良三, 大内重男, 安平 進：高化，13，38(1956)

\title{
Studies on Thermal Degradation Products of Polymers by Gas Chromatograph
}

\section{Polyethylene}

\author{
By Hirotaro Kambe* and Yoshio Shibasaki*
}

\begin{abstract}
Several commercial polyethylene were pyrolyzed with a simple apparatus at a relatively low temperature (about $320^{\circ} \mathrm{C}$ ), and thermal degradation products were analyzed with a gas chromatograph. Peaks of the chromatogram were identified systematically using Tenney's plots. Principal products were normal paraffins and olefins with carbon numbers of $7 \sim 9$, which were liquid at room temperatures. Normal paraffins and olefins of the same carbon number were produced in the nearly equal amounts.

The amounts of gas fraction of pyrolyzed products were very little. As a small amount of ethylene monomer is in the gas fraction, the main mechanism of the degradation of polyethylene seems to be the random scission of the main chain.
\end{abstract}

* Aeronautical Research Institute, the University of Tokyo (856, Komaba, Meguro-ku, Tokyo) 